\title{
Medical students writing letters to their patients: Teaching communication and empathy
}

\author{
Ivan Damjanov
}

\author{
Department of Pathology \\ The University of Kansas \\ School of Medicine \\ Kansas City, USA \\ Corresponding author: \\ Department of Pathology \\ The University of Kansas \\ School of Medicine \\ 3901 Rainbow Blvd \\ Kansas City, KS 66160, USA \\ idamjano@kumc.edu \\ Tel.: + 9135887090 \\ Fax: + 9135888780
}

Received: 7 March 2012

Accepted: 9 Mrach 2012

Copyright (C) 2012 by Academy of Sciences and Arts of Bosnia and Herzegovina. E-mail for permission to publish: amabih@anubih.ba
This Editorial was written as an encomium to Doctors Mrduljaš-Đujić, Pavličević, Marušić and Marušić to acknowledge their contributions to medical education in the article they have authored for this issue of Acta Medica Academica (1). However, before I address the key features of that article allow me first to describe the problems of teaching humanism in medical schools, at least the way I see them.

Over the last 150 to 200 years the medical knowledge has grown at an exponential rate. Reflecting this fact and the needs of the society, the medical educators have tried to keep pace with the scientific advances, while at the same time preserving the traditions of medical humanism. A typical see-saw conflict ensued between the technocrats and basic scientists on one side, and the humanists and the socially minded providers of health care on the other. In most medical schools the scientific camp has been winning the minds and the hearts of most medical students, and thus dominating the battlefield. Since confrontations rarely solve the problems, the main issues of medical education remain unresolved.

Like the society in general, medical educators have been fascinated by technological advances. The teaching of art and science of medicine has been replaced by teaching or science at the expense of art. Imprinted by their role models, the professors practicing technology driven medicine, the graduating physicians began entering preferentially into subspecialties of internal medicine and surgery requiring complex instrumentation, narrow specialization, and high efficiency. The field of general medicine, based on the practice of compassionate but 
time consuming interaction between the doctor and his/her patients, became less attractive and understaffed in many advanced countries. In the USA, physician assistants and nurse practitioners have replaced in many places the medical doctors and often function as the primary care providers. The proliferation of alternative medicine, a multibillion dollar industry worldwide, has been yet another consequence of the lack of dedicated primary care physicians who are willing to listen to patient's complaints and try to compassionately solve them.

The reasons why medical students choose more lucrative careers in subspecialties of clinical medicine and forego family practice are in part financial and in part societal. Medical educators are not entirely faultless in this context, but admittedly, some problems are hard to solve. For example, as an academic pathologist teaching pathology as the basis of medical practice, I am probably luring some students away from family practice. Since pathology is a combination of basic sciences and clinical medicine, my task in convincing students to study hard and dream about a clinical specialty is relatively easy. At the same time I have witnessed year after year the Sisyphean efforts of my family practice colleagues teaching, what the students call colloquially "soft subjects", such as Introduction to clinical reasoning, Medical ethics, Medical deontology, or Medical professionalism. The reality of medical education is that is the students spend more time dissecting cadavers, studying nerve conduction, or the motility of the intestines rather than the art of communication with the patient.

How could we, as a team of teachers, convince students that the art of communication is more important for their future practice than the tumor suppressor gene TP53? Especially since TP53 will be on the final examination and national examinations like United States Medical Licensing
Examination (USMLE). Furthermore, the knowledge of communication skills cannot be tested readily by multiple choice questions and those questions that show up on the exams can be answered by using common sense, as one medical student told me. International committees on medical education including the American Accreditation Council for Graduate Medical Education (ACGME) consider communication skills to be one of the essential skills, to be mastered by all medical students, but that will not convince too many students to take this task more seriously. Attempts to measure communication skills objectively have not been widely used except in psychometric studies $(2,3)$. Objective measurement of empathy, another crucial attribute of future physicians, has been studied scientifically (4), but translating scientific data into practice takes time and most medical schools still do not know how to teach empathy in practice.

Fascination with science, although essential for the future of evidence based medicine, must be counterbalanced by a more humanistic approach to medicine to meet the true needs of the society. The society is still expecting from medical schools to educate well rounded physicians, who will be capable of providing basic health care for the populace at large. Two key words loom large in this context: communication and empathy. These two words bring us back to the article by Mrduljaš-Đujić et al. (1), in which they describe their experience in "epistolary medicine" (5) with senior students from the School of Medicine in Split. Mrduljaš-Đujić et al. (1) show convincingly that the art of medicine is not dead and that it can be taught to medical students. By asking the medical students to write letters to their patients, the professors from Split have shown that a personalized experience can teach more than a formal lecture. Even more importantly, they demonstrate that students, if given a life - like experience, can live up 
to the professors expectations and clearly perform complex task requiring excellence in communication and high dose of empathy. Students from Split have in this teaching module shown not only a high level of literacy, but also an impressive command of medical facts, and a capacity to translate their knowledge into words understandable by a lay person. The students' letters translated from Croatian into English and published in this article illustrate the benefits of the epistolary approach (5) to teaching the art of communication in practice. Both the professors and students deserve kudos for their efforts and enthusiasm which could serve as examples to others. Paraphrasing an old article, that forestry cannot be learned out of a lumberyard (6), it is obvious that medical communication and empathy cannot be taught ex cathedra, and that in medical education, practice always trumps theory.

Conflict of interest: The author declares that he has no conflict of interest. This study was not sponsored by any external organisation.

\section{References}

1. Mrduljaš-Đujić N, Pavličević I, Marušić A, Marušić M. Students' letters to the patients as a part of education in family medicine. Acta Medica Academica. 2012;41(1): 52-8

2. Lang F, McCord R, Harvill L, Anderson DS. Communication assessment using the common ground instrument: psychometric properties. Fam Med. 2004;36:189-98.

3. Huntley CD, Salmon P, Fisher PL, Fletcher I, Young B. LUCAS: a theoretically informed instrument to assess clinical communication in objective structured clinical examinations. Med Educ. 2012;46:267-76.

4. Hojat M, Mangione S, Kane GC, Gonnella JS. Relationships between scores of the Jefferson Scale of Physician Empathy (JSPE) and the Interpersonal Reactivity Index (IRI). Med Teach. 2005;27:625-8.

5. Dolan B, Goren N, Perlis C.Epistolary medicine. Lancet. 2009;374:1588-9.

6. Verby JE, Schaefer MT, Voeks RS. Learning forestry out of the lumberyard. A Training alternative for primary care. JAMA 1981;24:645-7. 